\title{
THE INFLUENCE OF STONE CONTENT ON COMPACTION CHARACTERISTICS OF GRANULAR SOIL
}

\author{
Abdel-Aziz A. A. Senoon \\ Lecturer, Civil Engineering Department, Assiut University, Assiut, Agypt. \\ E-mail : asenoon2000@yahoo.ca
}

(Received October 10, 2006 Accepted November 2, 2006)

\begin{abstract}
Building on/or with compacted fill is common to many major construction projects. The engineering behavior of a soil depends on (among other things) the size distribution and the composition of the particles. The properties of a given soil can usually by significantly change by adding some selected soil. Large size particles have considerable importance in physical properties such as permeability, shear strength and load response especially for fine-grained soil.

The objective of this paper is the determination of the effect of stone content on the results of a compacted soil implementarly different compaction effort. Compaction tests were conducted on soil stone mixtures. A soil matrix is uniformly prepared by mixing selected amount of stone to the soil.
\end{abstract}

KEY WORLD: Granular soil, compaction, maximum dry density and optimum moisture content.

\section{INTRODUCTION}

Fine grained soils, notably clays are very commonly encountered are used as construction geomaterial. Due to their common occurrence and relatively impermeable nature, such soils are utilized in many major engineering projects, applications include embankment dam, liner for disposal landfills. Such fill materials especially boulder clay has on inclusions of very coarse materials in size of to cobbles and larger.

The large size of such inclusions may be of considerable importance in relation to physical properties such as permeability, strength and load response. The presences of very large particles reflect difficulties in the determination of strength and stress deformation properties by conventional laboratory equipment. Complications arising from the fact that the size of the laboratory specimen must big enough to ensure that the specimens represent the field situation of the mixed soil with stones, in order to assure valid results.

In order to determine the engineering properties of soil such as permeability, strength, compressibility and load response, using conventional apparatus, laboratory specimens have to be prepared excluding coarse particles. In effect correction should be implemented to the test results, a procedure which has been used in [1 to 5].

Kumar and Muir [6] performed fall-cone tests on mixtures of kaolinite and fine gravel passing from $3.35 \mathrm{~mm}$, and retained $2 \mathrm{~mm}$ size sieve. They stated that the liquid 
limit of the mixtures show a linear variation with clay content above $40 \%$ and a sharp change was observed with clay content below $40 \%$. They also, concluded that the presence of the coarse fraction will modify the mechanical behavior of the mixtures, the clay matrix governs the behavior if the coarse fraction is below $30 \%$ the gravel material acts as volume filler). Beyond this point the gravel starts to dictate the behavior.

The maximum dry density increases with the increasing aggregate content and peaks at $60-80 \%$. However optimum moisture content, O. m. c., and void ratio decreases with the increasing aggregate content until 60-70 \%, beyond this range the void ratio increased sharply $[7,8]$.

Anjajah et al [9] investigated the effect of aggregate content of up to $70 \%$ ranging from $4.75-19 \mathrm{~mm}$ size on the shear strength of compacted coarse-grained soils. Large and small shear boxes were used. In both series of the tests the increase in the vale of shearing resistance was noted up to aggregate content of $30 \%$ beyond this percentage the value of angle of shearing resistance decreased. No conclusive relationship could be established since at $70 \&$ aggregate, the angle of shearing resistance once again increased.

Fragaszy and Pond [10] investigated change in strength associated with the addition of $15 \%$ and $40 \%$ gravel particles to uniform sand. The results stated that the difference in strength showed to be significant only when $40 \%$ rounded particles were used.

The objective of this paper is the determination of the effect of stone content on the results of the compacted test $\left(\gamma_{d_{\max }}\right.$ O .M .C.) with different effort of compaction. Compaction tests were conducted on soil stone mixtures. A soil matrix is uniformly mixed to incorporate varying percentages of gravel.

\section{LABORATORY TESTING PROGRAM}

\subsection{Equipment And Materials Used}

\subsection{Equipment}

Proctor apparatus and tools used for the compact tests.

\subsubsection{Geomaterials}

The particles size distribution of the soil was used in the tests as shown in the Fig. (1). This soil has specific gravity, $\mathrm{G}_{\mathrm{s}},=2.65$, uniform coefficient, $\mathrm{C}_{\mathrm{u}}, 2.5$ and coefficient of curvature, $\mathrm{C}_{\mathrm{z}},=1.003$. Classified of soil is (SC) using unified soil classification. The consistency limits for the fine partion-passing sieve No. 40 are the following, Liquid limit and plastic limit are 30, 20.2 respectively. The size of gravel varies from $9.52 \mathrm{~mm}$ to $4.75 \mathrm{~mm}$ size and specific gravity, $\mathrm{G}_{\mathrm{s}},=2.65$ was used in the tests.

\section{2 Test arrangement}

Twenty-four (24) tests were conducted to determine the effective of the stone percentage on the results of compaction. These tests were conducted on seven different groups with different $\%$ of stone as shown in Table 1. The effort of compaction of all groups equal to 594,2104 and $2630 \mathrm{kN} \cdot \mathrm{m} / \mathrm{m}^{3}$ respectively. 


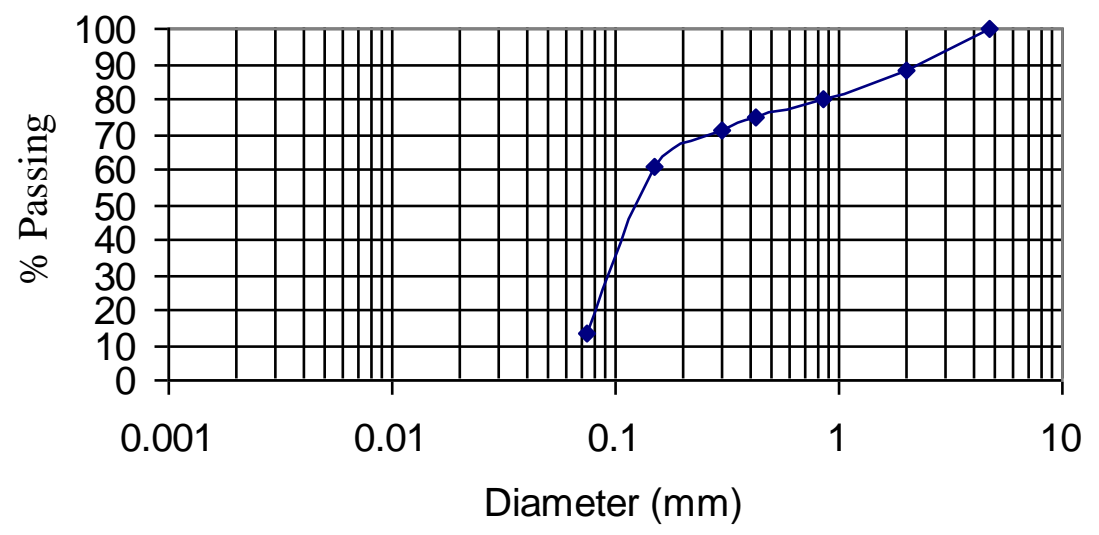

Fig.(1) Particle size distribution

Table 1: Results of the compaction tests.

\begin{tabular}{|c|c|c|c|c|c|c|c|c|c|}
\hline $\begin{array}{l}\text { Test } \\
\text { No. }\end{array}$ & $\begin{array}{l}\% \text { of } \\
\text { stone }\end{array}$ & $\begin{array}{l}\text { Type of } \\
\text { test }\end{array}$ & $\mathrm{n}$ & $\mathrm{N}$ & $\begin{array}{l}\mathrm{W} \\
(\mathrm{kg})\end{array}$ & $\begin{array}{c}\mathrm{H} \\
(\mathrm{cm})\end{array}$ & $\begin{array}{c}\text { C. E } \\
\text { kN.m/ } \\
\mathrm{m}^{3}\end{array}$ & $\begin{array}{l}\gamma_{d_{\max }} \\
\mathrm{t} / \mathrm{m}^{3}\end{array}$ & $\begin{array}{c}\text { O. m.c. } \\
\%\end{array}$ \\
\hline 1 & \multirow{3}{*}{0} & SPCT & 3 & \multirow{3}{*}{25} & 2.5 & 30.5 & 594 & 1.62 & 13 \\
\hline 2 & & BSMPCT & 4 & & 4.5 & 45 & 2104 & 1.72 & 11 \\
\hline 3 & & MPCT & 5 & & 4.5 & 45 & 2630 & 1.78 & 9 \\
\hline 4 & \multirow{3}{*}{5} & SPCT & 3 & \multirow{3}{*}{25} & 2.5 & 30.5 & 594 & 1.63 & 12 \\
\hline 5 & & BSMPCT & 4 & & 4.5 & 45 & 2104 & 1.73 & 10.5 \\
\hline 6 & & MPCT & 5 & & 4.5 & 45 & 2630 & 1.79 & 9 \\
\hline 7 & \multirow{3}{*}{10} & SPCT & 3 & \multirow{3}{*}{25} & 2.5 & 30.5 & 594 & 1.72 & 13 \\
\hline 8 & & BSMPCT & 4 & & 4.5 & 45 & 2104 & 1.79 & 11.2 \\
\hline 9 & & MPCT & 5 & & 4.5 & 45 & 2630 & 1.82 & 9.6 \\
\hline 10 & \multirow{3}{*}{15} & SPCT & 3 & \multirow{3}{*}{25} & 2.5 & 30.5 & 594 & 1.79 & 13 \\
\hline 11 & & BSMPCT & 4 & & 4.5 & 45 & 2104 & 1.82 & 11.5 \\
\hline 12 & & MPCT & 5 & & 4.5 & 45 & 2630 & 1.84 & 10 \\
\hline 13 & \multirow{3}{*}{20} & SPCT & 3 & \multirow{3}{*}{25} & 2.5 & 30.5 & 594 & 1.80 & 14 \\
\hline 14 & & BSMPCT & 4 & & 4.5 & 45 & 2104 & 1.85 & 12 \\
\hline 15 & & MPCT & 5 & & 4.5 & 45 & 2630 & 1.90 & 10 \\
\hline 16 & \multirow{3}{*}{25} & SPCT & 3 & \multirow{3}{*}{25} & 2.5 & 30.5 & 594 & 1.74 & 13.5 \\
\hline 17 & & BSMPCT & 4 & & 4.5 & 45 & 2104 & 1.80 & 13 \\
\hline 18 & & MPCT & 5 & & 4.5 & 45 & 2630 & 1.82 & 11 \\
\hline 19 & \multirow{3}{*}{30} & SPCT & 3 & 25 & 2.5 & 30.5 & 594 & 1.69 & 12 \\
\hline 20 & & BSMPCT & 4 & & 4.5 & 45 & 2104 & 1.76 & 10.5 \\
\hline 21 & & MPCT & 5 & & 4.5 & 45 & 2630 & 1.80 & 9 \\
\hline 22 & \multirow{3}{*}{35} & SPCT & 3 & 25 & 2.5 & 30.5 & 594 & 1.645 & 11 \\
\hline 23 & & BSMPCT & 4 & & 4.5 & 45 & 2104 & 1.765 & 10 \\
\hline 24 & & MPCT & 5 & & 4.5 & 45 & 2630 & 1.825 & 9.5 \\
\hline
\end{tabular}


Where:

$\begin{array}{ll}\mathrm{n} & \text { number of layers in mold } \\ \mathrm{N} & \text { number of drops for each layer } \\ \mathrm{W} & \text { weight of hammer } \\ \mathrm{H} & \text { high of hammer travel } \\ \mathrm{C} . \mathrm{E} & \text { compaction energy effort for the standard proctor compaction test } \\ \gamma_{d_{\max }} & \text { maximum dry density } \\ \text { O. m. c. } & \text { optimum water content } \\ \text { SPCT } & \text { standard proctor compaction test } \\ \text { MPCT } & \text { modified proctor compaction test } \\ \text { BSMPCT } & \text { between standard and modified proctor compaction test }\end{array}$

\subsection{Test Procedure Stone}

In order to eliminate surface dust from the stone a washer drum was used. Stone aggregate was washed for approximately 5 minutes, with the aggregate being moved during washing. The washed stone aggregate was spread out to allow free water to drain off. The clean, stone were then mixed thoroughly within soil sample to study the effect of $\%$ of stone on the compaction results.

\section{Specimen preparation}

The dry soil and the required amount of water were mixed for about 10 minutes. Stone was saturated and then surface dried before mixed. Clean surface dried stone aggregate weighed separately and then mixed thoroughly with the soil mixture for each particular percentage of soil stone mixtures. The soil- stone mixtures were then subjected to compaction using standard specification procedure.

All tests carried out according to standard specification methods [11]

\section{Test results}

Dry density of the compacted soil with a certain $\%$ of stone is plotted against mould water content at constant effort of compaction, as shown in Figs. 2 to $\mathbf{9}$. The maximum dry density and optimum moisture content were taken from the curves and recorded in Table 1. All plotted curves indicated that the maximum dry density $\left(\gamma_{d_{\max }}\right)$ increases as the effort of compaction increases at the same percentage of stone. But the optimum moisture content decreases with the increasing of the effort of compaction at certain $\%$ of stone.

\section{ANALYSIS AND DISCUSSION OF TEST RESULTS}

The following discussion illustrates the effect of the $\%$ of stone and effort of compaction on the results of compaction, $\left(\gamma_{d_{\max }}\right.$, O. M.C.).

\subsection{Results Of Compaction}

A summary of maximum dry density and optimum water content results are given in Table 1. 


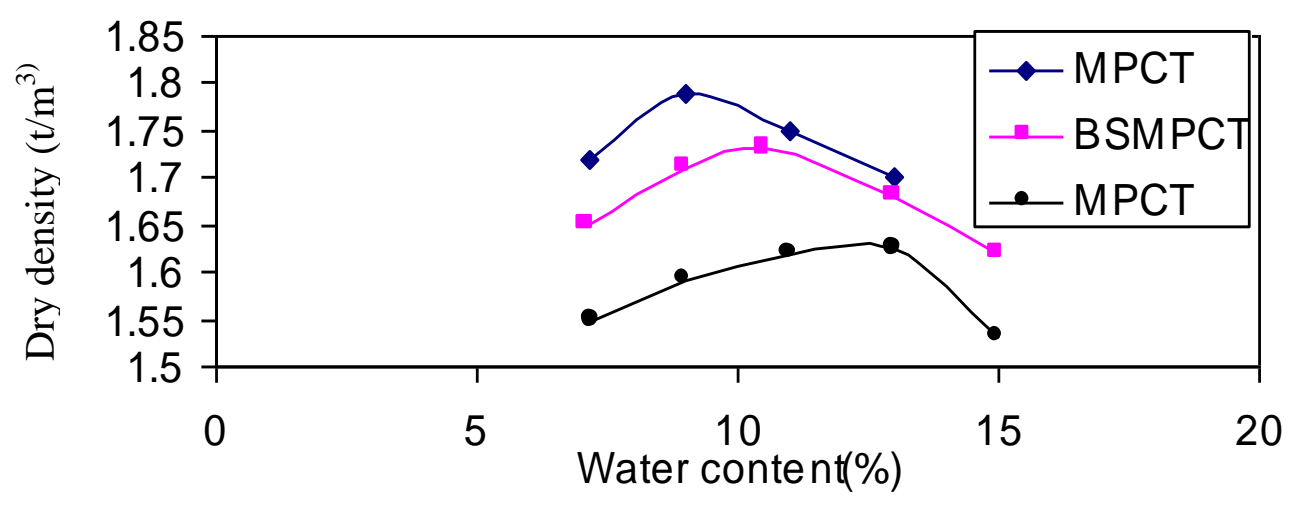

Fig. 2: Dry density vs water content at $0 \%$ of stone.

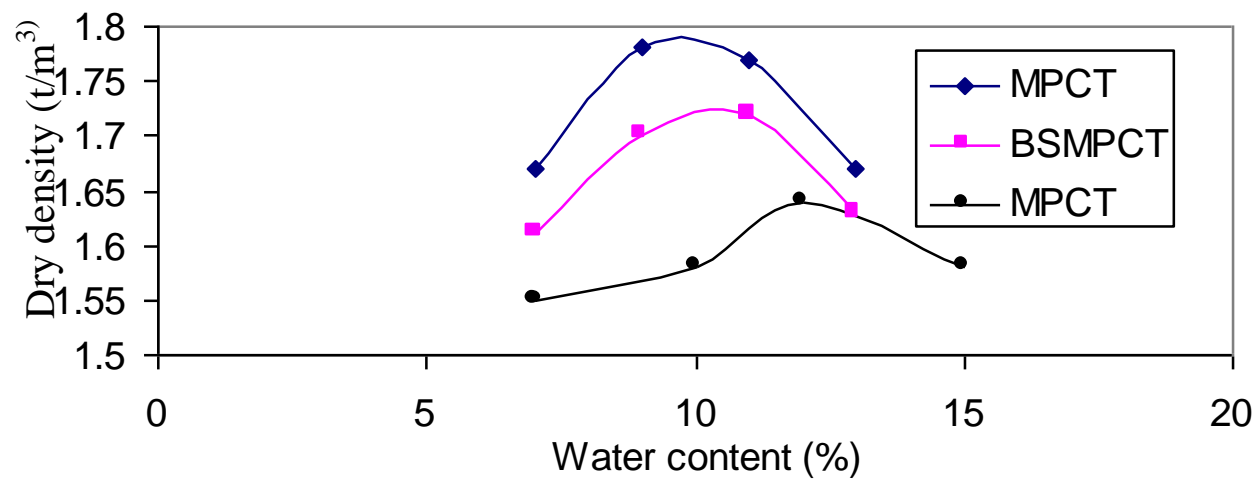

Fig. 3: Dry density vs water content at $5 \%$ of stone.

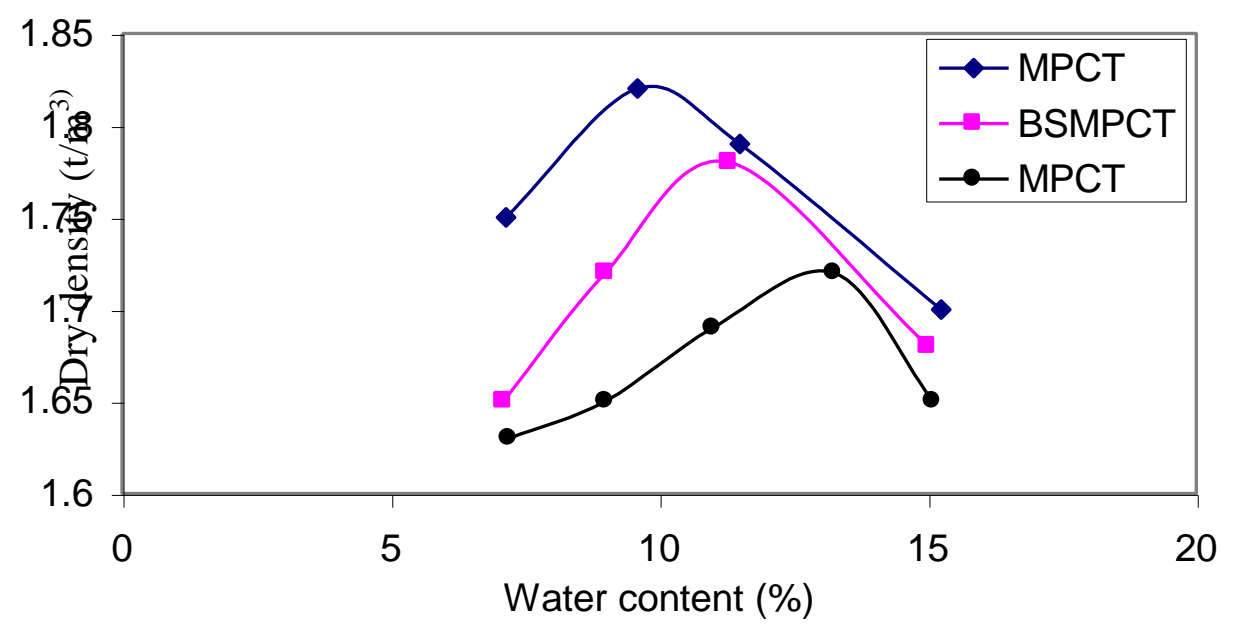

Fig. 4: Dry density vs. water content at $10 \%$ of stone. 


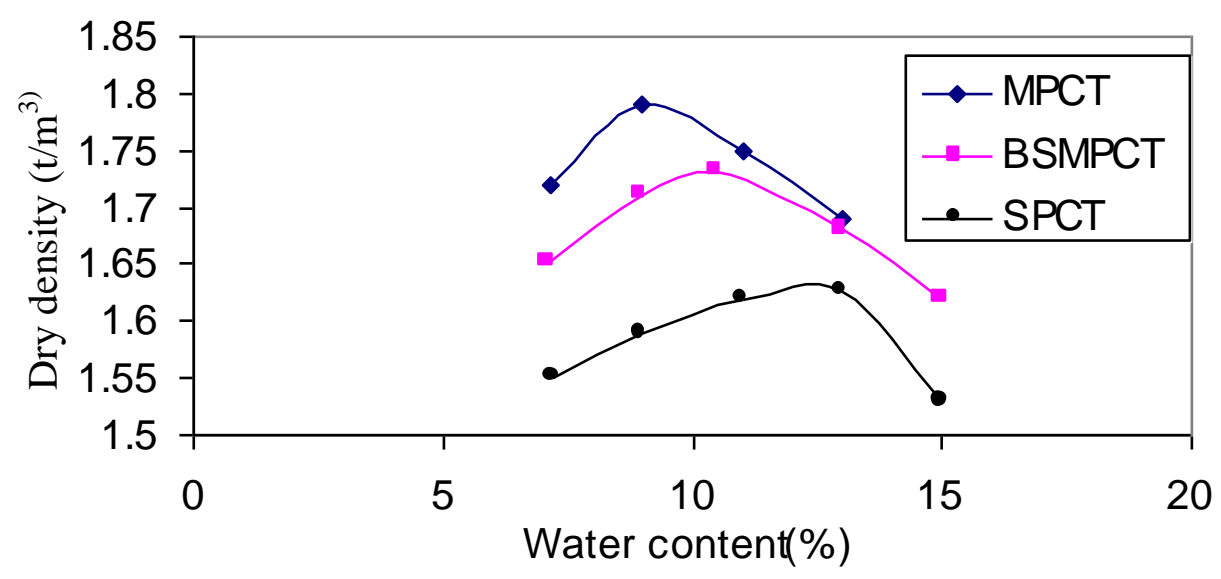

Fig. 5: Dry density vs. water content at $15 \%$ of stone.

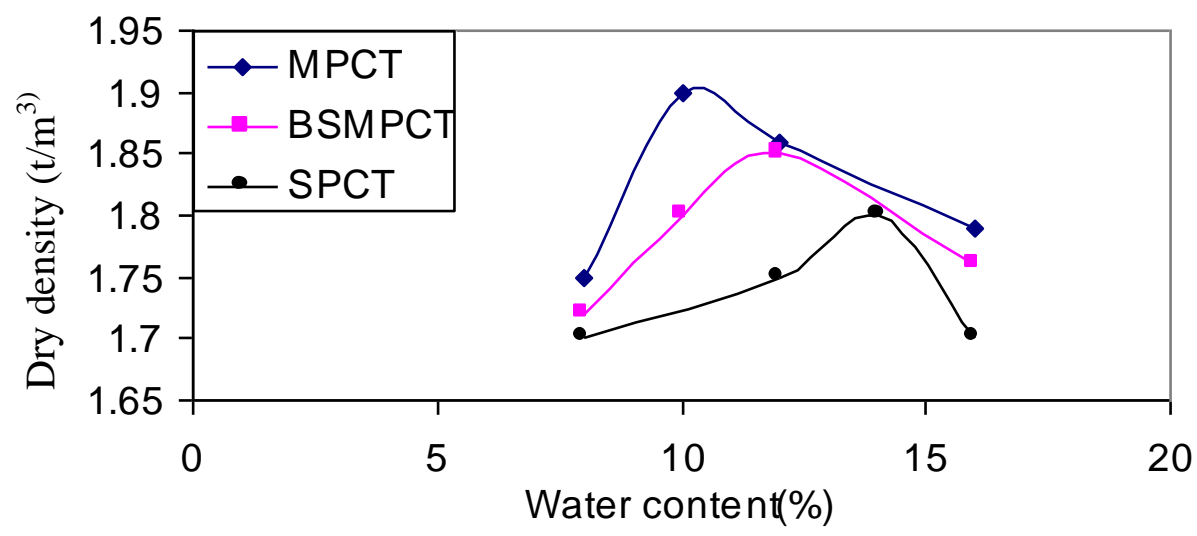

Fig. 6: Dry density vs. water content at $20 \%$ of stone.

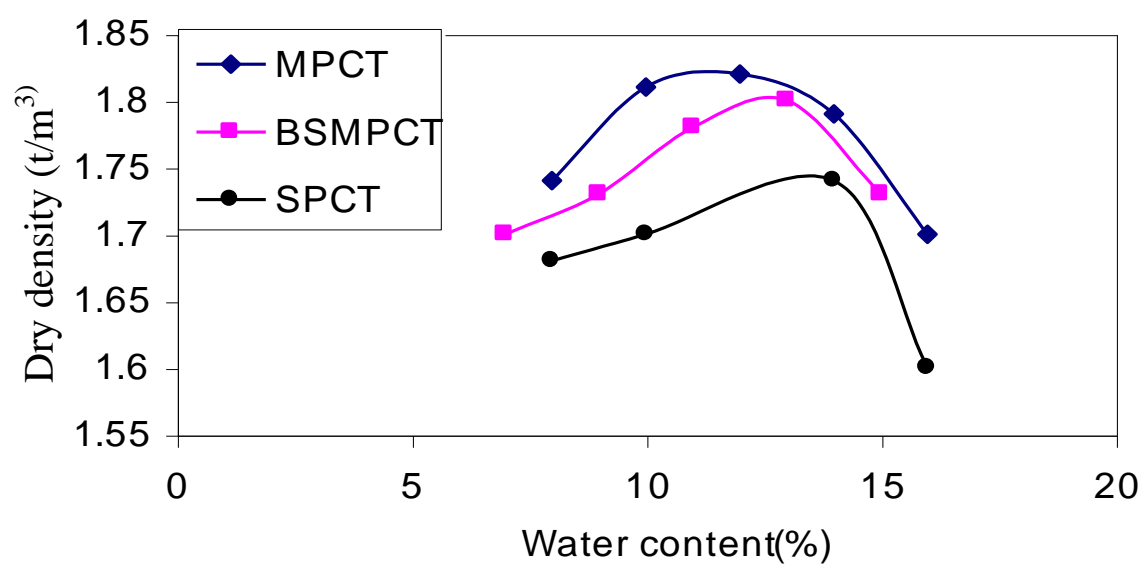

Fig. 7: Dry density vs. water content at $25 \%$ of stone. 


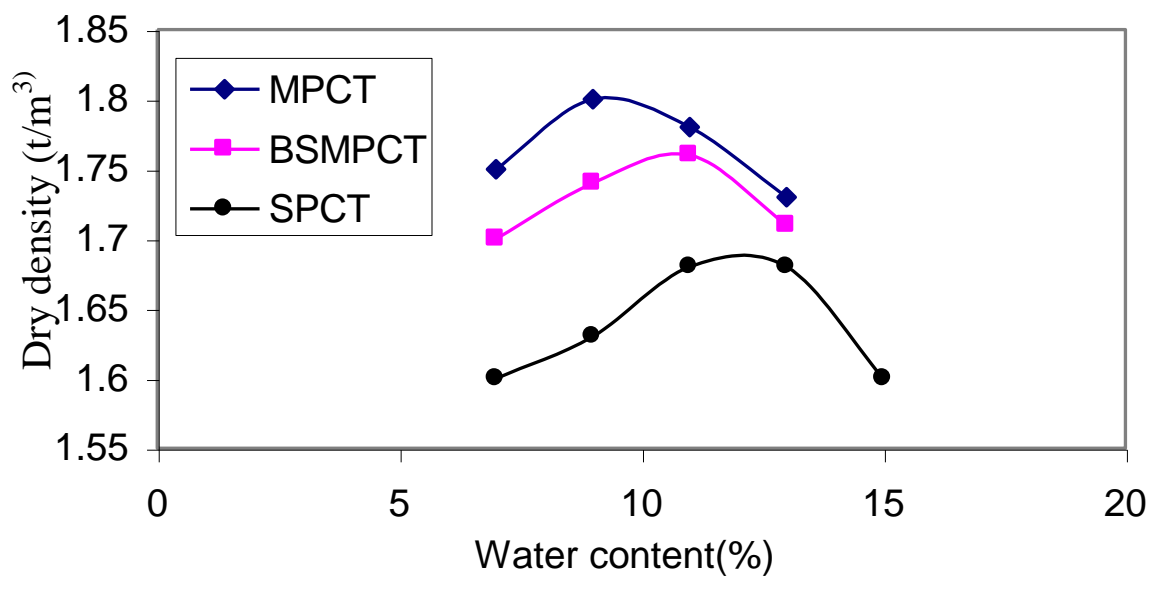

Fig. 8: Dry density vs. water content at $30 \%$ of stone.

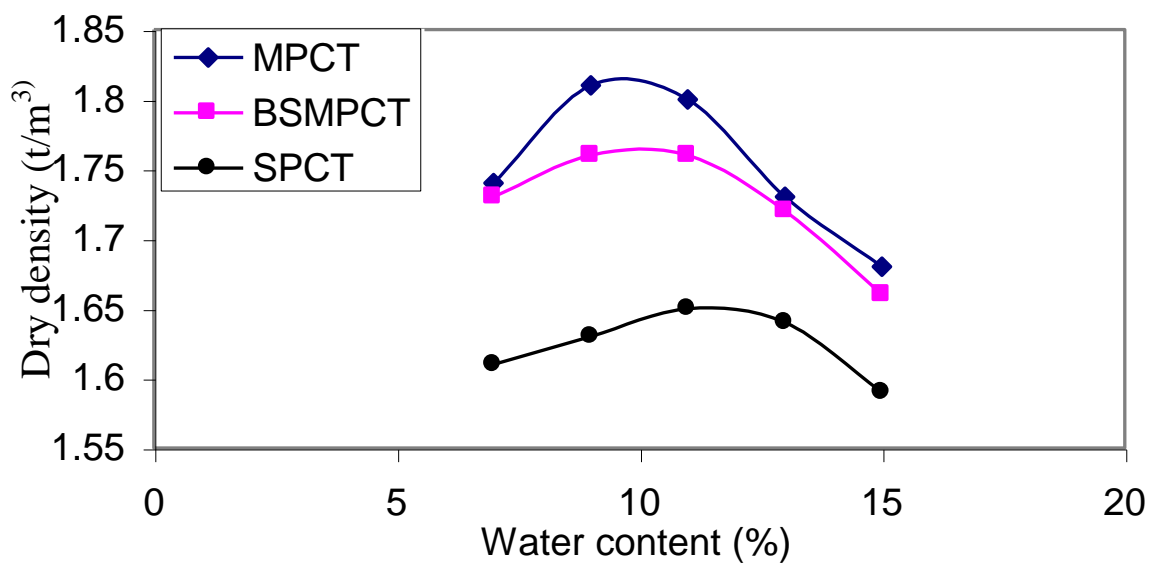

Fig. 9: Dry density vs. water content at $35 \%$ of stone.

\subsubsection{Maximum dry density}

The values of the maximum dry density are plotted against the study parameters (\% of stone and effort of compaction energy), as shown in Fig. 10. At all tests the maximum dry density increases as the $\%$ of stone increases until $\%$ of stone equal to $20 \%$ at certain effort of compaction. This is mainly due to the fine particle of soil fill the void between coarse particles of stone with no change of volume. After that, the maximum dry density decreases with the increasing $\%$ of stone. This is due to; there was an insufficient fine material to fill the voids between coarse stone. More and more stone particles were thus in direct contact with each other preventing full compaction of the fines between stone particles. Curves show that the maximum dry density increases as effort of compaction increases at same \% of stone 


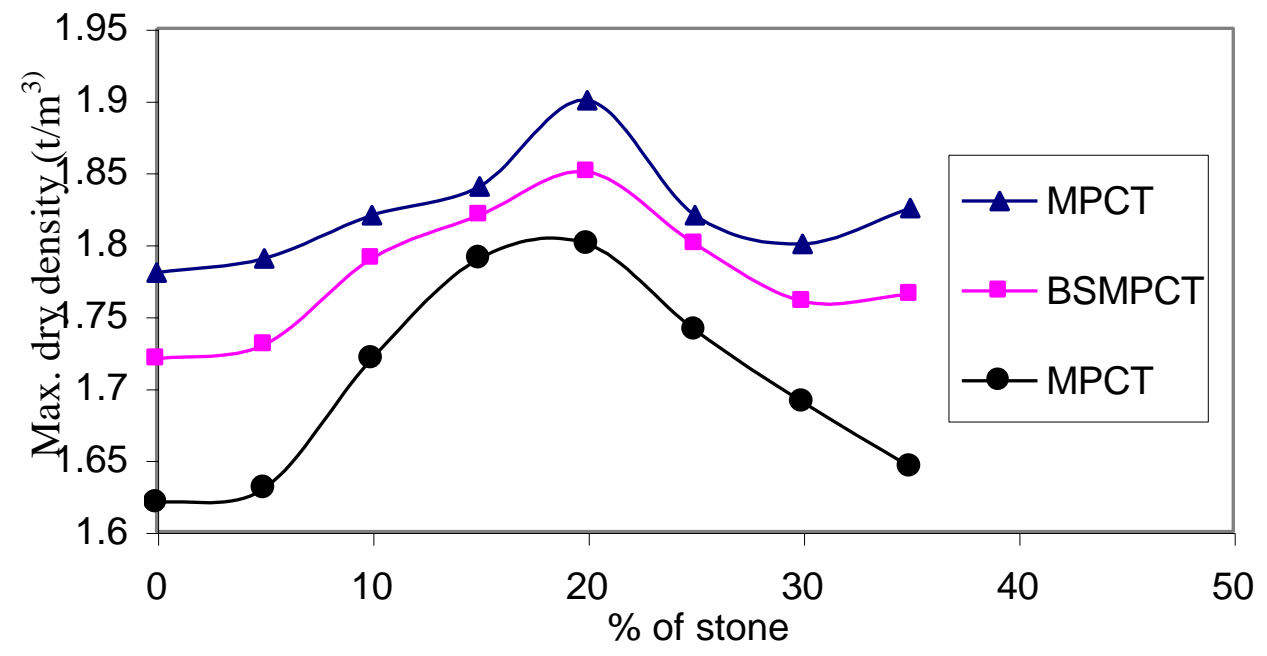

Fig. 10: Maximum dry density vs. \% of stone at different effort of compaction.

$\mathbf{R}_{\text {C.E. }}$ and $\mathbf{R}_{\gamma}$ for all tests are given in Table 2. The given values are plotted at the different $\%$ of stone, as shown in Fig. 11.

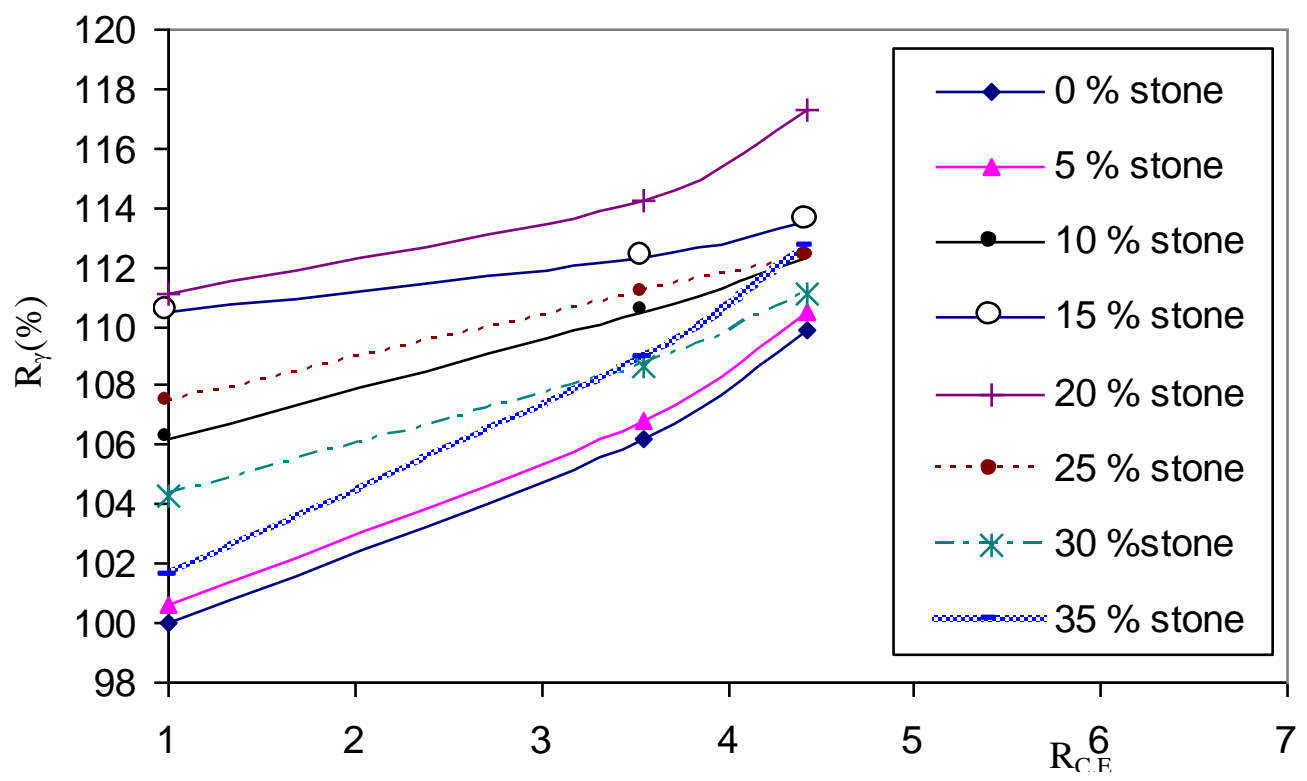

Fig. 11: RC.E. Vs. $R_{Y}(\%)$ at different \%of stone. 
Table 2: Analysis of the compaction test results.

\begin{tabular}{|c|c|c|c|c|c|c|c|}
\hline $\begin{array}{l}\text { Test } \\
\text { No. }\end{array}$ & $\begin{array}{l}\% \text { of } \\
\text { stone }\end{array}$ & $\begin{array}{l}\text { Type of } \\
\text { test }\end{array}$ & $\begin{array}{c}\text { C.E. } \\
\mathrm{kN} . \mathrm{m} / \mathrm{m}^{3}\end{array}$ & $\begin{array}{c}\boldsymbol{C . E} \\
\begin{array}{c}\text { C.E } \\
= \\
\text { SPCT }\end{array} \\
\left(\mathrm{R}_{\text {C.E. }}\right)\end{array}$ & $\begin{array}{l}\gamma_{d_{\max }} \\
\mathrm{t} / \mathrm{m}^{3}\end{array}$ & $\begin{array}{l}\frac{\gamma_{d_{\max }}}{\gamma_{d_{\max (S P C T(0))}}} \\
=\left(\mathrm{R}_{\gamma}\right) \%\end{array}$ & $\begin{array}{l}\text { O.M.C } \\
\text { c. } \%\end{array}$ \\
\hline 1 & \multirow{3}{*}{0} & SPCT & 594 & 1 & 1.62 & 100 & 13 \\
\hline 2 & & BSMPCT & 2104 & 3.543 & 1.72 & 106.17 & 11 \\
\hline 3 & & MPCT & 2630 & 4.428 & 1.78 & 109.87 & 9 \\
\hline 4 & \multirow{3}{*}{5} & SPCT & 594 & 1 & 1.63 & 100.62 & 12 \\
\hline 5 & & BSMPCT & 2104 & 3.543 & 1.73 & 106.80 & 10.5 \\
\hline 6 & & MPCT & 2630 & 4.428 & 1.79 & 110.49 & 9 \\
\hline 7 & \multirow{3}{*}{10} & SPCT & 594 & 1 & 1.72 & 106.17 & 13 \\
\hline 8 & & BSMPCT & 2104 & 3.543 & 1.79 & 110.49 & 11.2 \\
\hline 9 & & MPCT & 2630 & 4.428 & 1.82 & 112.34 & 9.6 \\
\hline 10 & \multirow{3}{*}{15} & SPCT & 594 & 1 & 1.79 & 110.49 & 13 \\
\hline 11 & & BSMPCT & 2104 & 3.543 & 1.82 & 112.34 & 11.5 \\
\hline 12 & & MPCT & 2630 & 4.428 & 1.84 & 113.58 & 10 \\
\hline 13 & \multirow{3}{*}{20} & SPCT & 594 & 1 & 1.80 & 111.11 & 14 \\
\hline 14 & & BSMPCT & 2104 & 3.543 & 1.85 & 114.20 & 12 \\
\hline 15 & & MPCT & 2630 & 4.428 & 1.90 & 117.28 & 10 \\
\hline 16 & \multirow{3}{*}{25} & SPCT & 594 & 1 & 1.74 & 107.41 & 13.5 \\
\hline 17 & & BSMPCT & 2104 & 3.543 & 1.80 & 111.11 & 13 \\
\hline 18 & & MPCT & 2630 & 4.428 & 1.82 & 112.34 & 11 \\
\hline 19 & \multirow{3}{*}{30} & SPCT & 594 & 1 & 1.69 & 104.32 & 12 \\
\hline 20 & & BSMPCT & 2104 & 3.543 & 1.76 & 108.64 & 10.5 \\
\hline 21 & & MPCT & 2630 & 4.428 & 1.80 & 111.11 & 9 \\
\hline 22 & \multirow{3}{*}{35} & SPCT & 594 & 1 & 1.645 & 101.54 & 11 \\
\hline 23 & & BSMPCT & 2104 & 3.543 & 1.765 & 108.95 & 10 \\
\hline 24 & & MPCT & 2630 & 4.428 & 1.825 & 112.65 & 9.5 \\
\hline
\end{tabular}

Where: -

$\mathrm{R}_{\text {C.E. }} \quad$ ratio between compaction energy of the test to compaction energy of (SPCT)

$\mathbf{R}_{\gamma} \quad$ ratio between the max dry density of the test to the max dry density of (SPCT) at $0 \%$ of stone.

The relationship between $\mathrm{R}_{\text {C.E. }}$ and $\mathrm{R}_{\gamma}$ for the different $\%$ of stone may represented for the soil tests by the following expression: 


$$
\mathrm{R}_{\gamma}(\%)=\mathrm{a} \mathrm{R} \text { C.E. } \quad+\mathrm{b}
$$

where $\mathrm{a}, \mathrm{b}$ are constant obtained by regression formula, as the following:

$\begin{array}{cccc}\% \text { of stone } & \mathrm{a} & \mathrm{B} & \mathrm{R}^{2} \\ 0 & 2.7787 & 97.037 & 0.9835 \\ 5 & 2.7800 & 97.657 & 0.9838 \\ 10 & 1.7770 & 104.32 & 0.9980 \\ 15 & 0.8622 & 109.56 & 0.9749 \\ 20 & 1.6705 & 109.20 & 0.9277 \\ 25 & 1.4428 & 105.97 & 0.9990 \\ 30 & 1.9182 & 102.29 & 0.9865 \\ 35 & 3.1672 & 98.241 & 0.9934\end{array}$

\subsubsection{Optimum moisture content (\%)}

The values of the optimum moisture content (O. M.Cc.) for all tests are plotted against the study parameters (\% of stone and effort of compaction energy), as shown in Fig. 12. It should be noted that for all test the optimum moisture content does not show any definite trend with the increase in stone content.. However, optimum moisture content decreases with the increasing effort of compaction at a certain $\%$ of stone.

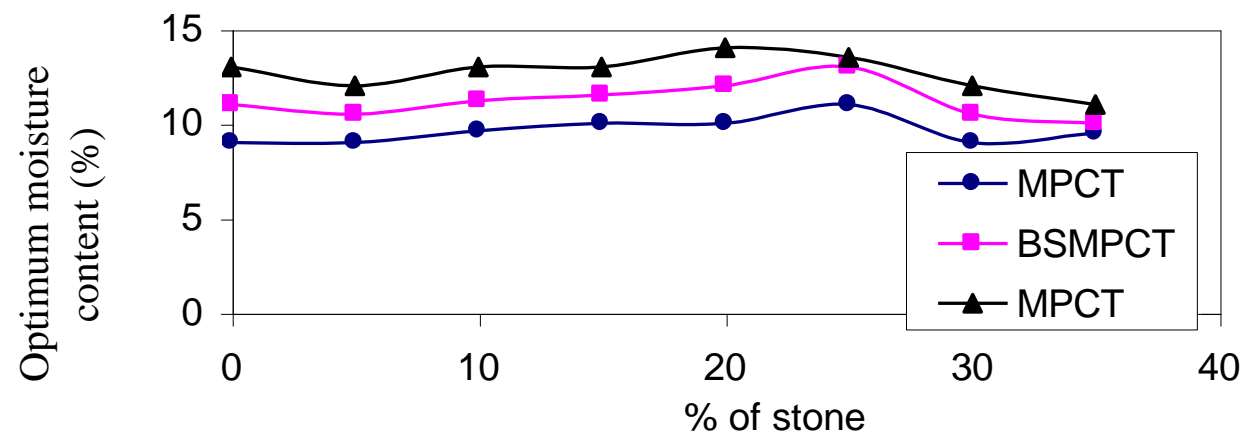

Fig. 12: Optimum moisture content vs. \%of stone at different effort of compaction.

\section{CONCLUSIONS}

The following conclusions can be drawn out from the present study:

- $\quad$ Maximum dry density $\left(\gamma_{d_{\max }}\right)$ increases with the increasing \% of stone until 20 $\%$ of stone, after that decreases with increasing $\%$ of stone at certain effort of compaction.

- $\quad$ Optimum moisture content (O. M.C) does not show any definite trend with the increase in stone content. However, optimum moisture content decreases with the increasing effort of compaction at a certain $\%$ of stone. 


\section{REFERENCES}

[1] Blotz, R. L. Benson, C. H. \& Boutwell, P. (1998).” Estimating optimum water content and maximum dry unit weight for compacted clay." Journal of Geotechnique Geoenviromental Engineering 124, No. 9, 907-912

[2] Gurtug, Y, \& Sridharan(2002)." Prediction of compaction characteristics of fine-grained soils." Technical notes, Geotechnique 52, No. 19, 761-763

[3] Mitchell, J. K. (1981). “ Soil improvement. State of the art report " Proc. $10^{\text {th }}$ International Conf. Of soil mech. And Foundation Eng., A. A. Balkema, Stockholm, Sweden, 4, 509-565

[4] Simms, P. H. \&Yanful. E. K. (2002). " Predicting soil- water characteristic curves of compacted plastic soils from measured pore-size distributions" Geotechnique 52, No. 4, 269-278.

[5] Foster, C. R. and E. J. Tunbull,: (1956) Stabilization of materials by compaction" J. soil Mechanics and Foundation Div. ASCE Vol. 82 No. SM2, April

[6] Kumar, G. V. and Muir Wood D. (1990)." Fall cone and compression tests on the clay-gravel mixtures, Geotechnique 49, pp. 717-739.

[7] Shakoor, A. and Cook, B. D. (1990). "Effect of stone content, size and shape on the engineering properties of compacted silty clay. Bulletin Assoc. Eng. Geologist. 27, pp 245-253

[8] Shelley, T.L. and Daniel, D. E. (1993) Effect of gravel on hydraulic conductivity of compacted soil liners. Journal of soil mechanics and foundation Engineering., 119, pp 54-67.

[9] Anjajah, B.;Babu, R. and Victor, P. (1994). "Effect of gravel content on shear strength of coarse grained soils." $59^{\text {th }}$ Research and development session, Calculta: India, 245-246.

[10] Fragaszy, R. J. and Pond, E. (1995) “ Strength of gap-graded gravelly soils." Geotechnical special publication, issue 56, New York pp20.24

[11] Egyptian code for soil mechanics and foundation design (2000)

\section{تأثير نسبة الحصى على خصائص التربة المدموكة}

عديد من المنشات تنشأ من أو على الردم المدموك و الخصائص الهندسية للتربة المدموكة تعتمد جزءا على حجم الحبيبات وتوزيعها. ويمكن تغير هذه الخواص بإضافة تربة أخرى الخى مختارة

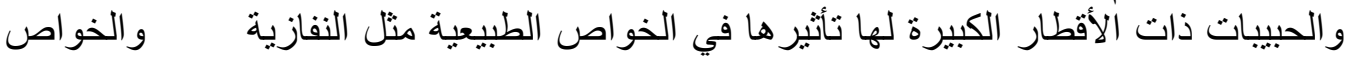

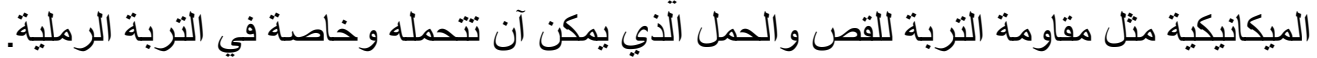

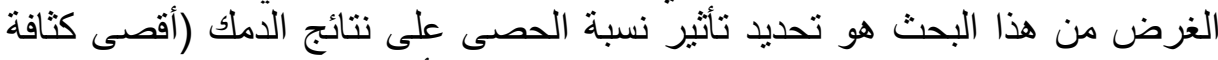

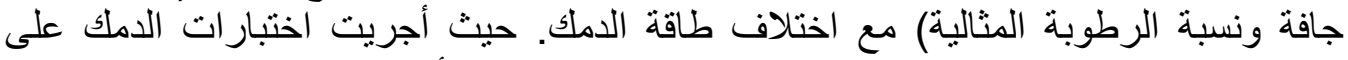
خليط متجانس من التربة ونسبة من الحصى وكانت النتائج كالأتي:- كلما زادية ادت نسبة الحصى التصى

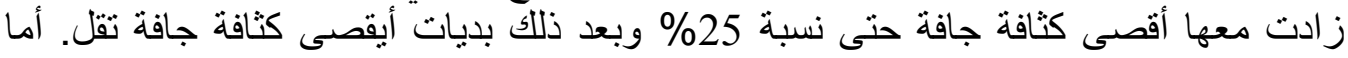

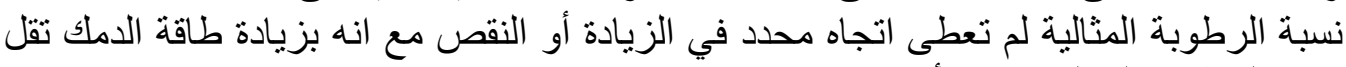
نسبة الرطوبة المثالية وتزيد أقصى كثافة جافة لمافة 